\title{
Nuestra cultura filosófica
}

Nuestra, ciertamente, porque estos países iberoamericanos poseen unidad en su formación ideológica. La hay en la Filosofía que se ha enseñado, desde las primeras corrientes, inevitablemente tomistas y aristotélicas del siglo XVI, hasta nuestros días; y es necesario ordenar los materiales existentes, formar el corpus filosófico, que si no registra aportes originales, tiene momentos de interés, y en todo caso, muestra la filiación europea del pensamiento en Iberoamérica. Ya el docto americanista don Aníbal Sánchez Reulet fijó en un trabajo muy breve pero denso los lineamientos de esta disciplina entre nosotros.

Los estudios literarios organizan de día en día la producción hispanoamericana. Se va haciendo el recuento y la revisión de lo pasado con el doble objeto de precisar valores y de que resalte el hilo de la tradición. No sirve ésta de pauta sino de raíz y de testimonio. La nacionalidad se funda, entre otros factores, en fuerzas de tradición. Lo actual, solo, desvinculado, ni logra cohesión ni edifica en el sér histórico. Lo que ya se va consiguiendo en la historia literaria, urge hacerlo en Filosofía, ya que ésta, por modo bien órgánico y hondo, denuncia las direcciones cardinales, no sólo del espiritu individual, sino de las sociedades.

Apenas hay movimiento filosófico en Europa, en el largo andar de su cultura, que no haya tenido alguna resonancia en 
estos países de habla hispánica o portuguesa. Primero tomismo y peripato; luego cartesianismo, ya sigiloso, ya mesurado; $y$ pensamiento dieciochesco, y positivismo del siglo XIX, $\mathrm{y}$ hegelianismo, y filosofía escocesa, y. evolucionismo spenceriano.

Hay en Cuba - país de sorprendente continuidad filosófica, desde los días del P. José Agustín Caballero-, un momento de mucho contenido. Me refiero a la polémica suscitada en torno a Víctor Cousin, por 1839. Aquello dejó algo: la Impugnación de Luż y Caballero a lás doctrinas de Cousin, único escritó filosófico extenso del pensador y educador cubano. No debe pasar este año de 1939 sin que en algún modo conmemoremos el centenario de tan significativo episodio que sólo menciono aquí.

Hacia la misma fecha de 1839 , se agitaban los círculos intelectuales de Santiago de Chile por cuestiones ideológicas. : Don Andrés Bello ejercía allí su sapiente magisterio.: Como se sabe, a más de filólogo y jurista, a más de gramático y poeta, era filósofo, si no de doctrina propia, al menos de clarisimo talento para asimilar y exponier ideas en este género de estudios. Pronto una parte de la juventud discrepó de la tendencia conservadora de don Andrés. Lastarria ctrenta con pormenores el proceso de la controversia. Lo vital, como en el caso de Cuba por igual fecha, era lo social, lo político; pero la pugna giró alrededor de doctrinas filosóficas. Fueron dos movimientos muy similares por el alcance que se atribuyó - por Luz en Cuba y por los impugnadores de Bello en Chile- a determinadas ideás. Y.hasta fué Cousin en Santiago de Chile una de las figuras europeas, motivo de debate.

Sólo he querido recordar, sin relato, dos peripecias de la filosofia en nuestros pueblos hermanos. Expuestos y puntualizados por entero esos dos momentos, dejan percibir la preocupación de las minorias por el género de enseñanza que iba a formar la conciencia social. No acabamos de ver que lo filosófico, aun lo más metafísico, desemboca al fin en la-realidad, en los 
criterios cotidianos, en hechura misma del Estado. $\mathrm{Ni}$ la $\mathrm{Li}$ teratura ni la Filosofia pueden estudiarse o enseñarse como actividades espirituales extrañas a la convivencia social humana. Al profesor se le olvida a veces ese latido de lo real.

Claro que primero hay que contar con la historia filosófica de aquellos países donde positivamente hay tradición a ese respecto. Cuando menos, existió en cualquier país nuestro la enseñanza escolástica, $\mathrm{y}$ a veces de su seno surgían voces disonantes, innovadoras.

En lo concerniente a Cuba, lo más aportador lo he reseñado en mi libro Varona y en Las ideas en Cuba; pero trabajo en una historia sistemática, orgánica, de la filosofía en esta Antilla.

En México esta materia se articula mediante no pocas figuras, algunas muy atendibles. La obra de Gabino Barreda, de Caso y de Vasconcelos, merece detenimiento.

En Argentina, don Alejandro Korn, hace poco desaparecido, animó, en su cátedra de la Universidad de Buenos Aires y en sus conversaciones, el espíritu filosófico. Quizás sea Argentina, actualmente, el país de América con intereses filosóficos más intensos y mejor orientados. El doctor Francisco Romero trabaja sin tregua y difunde sus escritos, que a Cuba al menos llegan con frectencia. Los del uruguayo Vaz Ferreira no circulan tanto, lo cual es de lamentarse. Don Enrique Molina, en Chile, compone libros discretos, de loable condición. Profesores y estudiosos de acá y de allá pueden citarse, no pocos de valer.

Por supuesto, las corrientes han sido más numerosas en los últimos cincuenta años. Los países donde se estudia más el alemán, como Argentina, Uruguay y Chile, evidencian más familiaridad envidiable con las direcciones múltiples del pensamiento en Alemania, en los últimos tiempos.

Sería jugoso tema determinar dónde y cómo hemos superado el Positivismo y dónde se mantuvo fiel al Comte de la primera época. Varona, por ejemplo, no siguió los movimientos 3 * 
generados por el neokantismo. Después de sus cursos de I880, apenas trabajó en filosofía. Centró sus actividades sobre todo en la política honesta, creadora, y en la crítica literaria, de la que fué alto maestro.

Densos serán los capítulos destinados a la Filosofía iberoamericana en los últimos decenios. Creo que la originalidad es poca, pero la preocupación por los problemas fundamentales del hombre y de la vida ha sido creciente. Nos importa ver el cuadro en su lucimiento integral.

Medardo Vitier. 